Jurnal MAKSIPRENEUR, Vol. VI, No. 1, Desember 2016, hal. 77 - 87

\title{
PENGEMBANGAN KAPASITAS DAN KELEMBAGAAN KELOMPOK PEMBERDAYAAN EKONOMI BERBASIS KEWILAYAHAN (PEW)
}

Bening Hadilinatih(linatih@yahoo.com)

Fakultas Ilmu Sosial dan Politik, Universitas Proklamasi 45

Susi Widjajani(susiwijayani@gmail.com)

Fakultas Ekonomi Universitas Proklamasi 45

ABSTRACT. Hidayah PEW group and Khasanah PEW group, in Village Pringgokusuman, District of Yogyakarta Gedong Tengen, a group of beneficiaries of Area Based Economic Empowerment Program in the city of Yogyakarta. Currently these two groups on the problem: 1). The weakness of the organizational aspects of the institutional group, yet have the institutional rules are clear, 2) Still Weak aspects of group administration, system administration and financial management is still very simple, 3) Low skills of administrators in the management of savings and loans, the ability of the management of the organization low group 4). The low activity is productive business (entrepreneurship) members. To help overcome the problems in both groups of partners, it will do service activities using the approach of counseling, training and mentoring. The training consists of training the administrative and accounting groups, institutional management and Cooperative Training, Computer Training \& Practice (Ms.Word \& Ms Excel), entrepreneurship training and counseling regarding the procedure for the preparation of Statutes and Bylaws.

Participants of the training consisted of officials from each of the partners. The objectives and targets to be achieved from each activity are as follows: 1) Extension of the procedure for preparing the Statutes and Bylaws; to improve the knowledge and ability to prepare a document for Statutes and Bylaws group. 2). Training Administration and accounting group; to improve the knowledge and skills of participants in financial administration and bookkeeping savings group savings and loan accounting .. 3). institutional and cooperative management training; that the board had knowledge of the institutional and cooperative management. 4) computer training; to improve the knowledge and skills to use computers as supporting the administration of the savings group. 5) entrepreneurship training; to improve understanding of entrepreneurship and increased interest, the spirit of entrepreneurship, and increasing entrepreneurial activity of the participants.

Target to be gained from the mentoring activities are: 1) orderly administration PEW Group includes the administrative requirements of the organization and financial adminstration 2). morale and motivation entrepreneurship 3). Improving the skills of the board to operate a computer for administrative support group. 4). Establishment of complete annual financial statements (statements Balance Sheet, of net income, Cash Flow Statements) 5). Job description Establishment Board.

Keywords: institutional management group - entrepreneurship - finance administration 


\section{PENDAHULUAN}

Kelompok PEW di Kelurahan Pringgokusuman merupakan Kelompok Pemberdayaan Ekonomi Wilayah yang dibentuk dengan tujuan untuk meningkatkan Usaha Mikro dan Kecil bagi para anggotanya. Sesuai dengan tujuan Program Pemberdayaan Ekonomi berbasis kewilayahan (PEW), masing-masing kelompok mendapat bantuan penguatan permodalan usaha, melalui program bantuan dana bergulir yang dikelola oleh kelompok sebagai pinjaman lunak dana bergulir dari badan Pemberdayaan Masyarakat. Dalam pelaksanaan kegiatannya Kelompok PEW belum memiliki aturan kelompok (AD/ART) yang tersusun secara sistematis sehingga program pengembangannya belum dapat direncanakan dengan baik, Pembagian tugas pengurus kurang jelas, hak dan kewajiban anggota belum dirumuskan dan belum terbentuk kaderisasi pengurus. Hal ini terbukti dengan tidak adanya pergantian kepengurusan karena tidak ada ketentuan tentang masa bakti pengurus. Fungsi-fungsi manajemen dalam pengelolaan organisasi kelompok belum diterapkan,dan administrasi keuangan masih sederhana. Sebagian besar anggota belum dapat memanfaatkan dana yang dipinjamnya untuk kegiatan-kegiatan usaha yang produktif yang dapat menghasilkan keuntungan. Dana pinjaman sebagaian besar dipergunakan untuk keperluan-keperluan hidup seharihari seperti untuk pembiayaan sekolah, biaya pengobatan, bahkan sebagian ada yang memanfaatkan dana pinjaman hanya untuk hal-hal yang bersifat konsumtif.

Kelompok PEW Hidayah dan Kelompok Chasanah, di Kelurahan Pringgokusuman, Kecamatan Gedongtengen, Kota Yogyakarta masing-masing memiliki 15 anggota yang sebagian besar adalah ibu rumah tangga .Tujuan dibentuknya kelompok ini adalah memenuhi kebutuhan modal atau kebutuhan lain yang tidak dapat dipenuhi secara individual. Pelayanan keuangan yang diselenggarakan oleh Kelompok PEW adalah menerima simpanan, memberikan pinjaman dan menyelenggarakan jaminan sosial. Simpanan terdiri dari simpanan pokok yang dilakukan sekali ketika menjadi anggota dan simpanan wajib yang dilakukan secara periodik setiap bulan Jaminan sosial yang diselenggarakan adalah bantuan perawatan kesehatan dan bantuan kematian. Dana jaminan sosial diambil dari sebagian keuntungan usaha. Pertemuan rutin diadakan setiap bulan pada minggu ketiga. Komunikasi telah terjalin diantara anggota, mereka saling mengenal dan sering terlibat dalam kegiatan kemasyarakatan secara bersama-sama. Hal ini menunjukkan bahwa dalam beberapa aspek, lembaga ini telah mengalami kemajuan. Namun demikian, lembaga ini belum mampu memenuhi pinjaman seluruh anggota sesuai dengan kebutuhannya. Ketidakmampuan Kelompok untuk memenuhi kebutuhan pinjaman sesuai dengan kebutuhan anggota menunjukkan kurangnya keswadayaan organisasi untuk memberikan pelayanan keuangan kepada anggota-anggotanya.

Pola pengelolaan usaha simpan pinjam belum bisa dijalankan dengan baik, disebabkan karena semua pengurus belum mendapat pengetahuan, pelatihan maupun penyuluhan mengenai pengelolaan/ manajemen kelompok dan administrasi keuangan simpan pinjam. Kedua kelompok ini masih menggunakan pencatatan pembukuan tradisional. Jenis dan Pengerjaan Administrasi Organisasi masih belum memadai, Jenis dan Pengerjaan Administrasi keuangan sangat sederhana. Seluruh proses pencatatan pada kegiatan administrasi keuangan ini, pada umumnya dilakukan secara manual. Hal ini menunjukkan Lemahnya keswadayaan organisasi .

Dalam kegiatan pengabdian pada masyarakat (IbM) yang dilakukan pada Kelompok PEW, yang dijadikan mitra adalah Kelompok PEW Hidayah dan Kelompok PEW Khasanah di Kelurahan Pronggokusuman Kecamatan Gedongtengen, Yogyakarta. 
Keberadaan kelompok PEW tersebut diharapkan dapat menunjang perekonomian anggotanya, terutama peranannya sebagai sumber pendanaan bagi para anggotanya, yang pada gilirannya akan berdampak pada kesejahteraan masyarakat pada umumnya. Kelompok pinjam juga dapat memberikan bantuan pinjaman kepada para anggotanya disaat anggota tersebut membutuhkan uang untuk pembiayaan sekolah, biaya pengobatan, dan lain sebagainya. Namun masih ada juga para anggota yang memanfaatkan pinjamannya hanya untuk hal-hal yang bersifat konsumtif atau dipergunakan untuk memenuhi kebutuhan hidup sehari-hari sehingga pemanfaatan pinjaman tersebut kurang dapat mengembangkan kegiatan usaha yang produktif hal ini disebabkan karena minimnya pengetahuan tentang kewirausahaan.

Berdasarkan hasil analisis situasi, hasil observasi, dan diskusi dengan kedua Mitra, teridentifikasi bahwa permasalahan-permasalahan utama yang perlu segera dipecahkan adalah sebagai berikut:

1. Masih lemahnya aspek organisasi kelembagaan Kelompok. Kedua kelompok belum memiliki aturan kelembagaan yang jelas.

2. Masih Lemahnya aspek administrasi kelompok. Jenis dan pengerjaan administrasi keuangan masih sangat sederhana.

3. Masih rendahnya ketrampilan pengurus dalam pengelolaan simpan pinjam.

4. Masih rendahnya usaha produktif anggota. Hal ini disebabkan karena terbatasnya pemahaman tentang kewirausahaan.

Berdasarkan permasalahan yang dihadapi kelompok PEW tersebut maka kegiatan Pengabdian Pada Masyarakat ini dilaksanakan untuk memberikan bantuan dalam mengatasi permasalahan yang dihadapi, dengan memberikan penyuluhan dan ketrampilan bagi pengurus dan anggota kelompok dalam hal-hal berikut:

a. Penguatan organisasi kelompok dan pengetahuan tentang tata cara penyusunan Anggaran dasar dan anggaran rumah Tangga (AD/ART) Kelompok PEW.

b. Peningkatan pemahaman bagi pengurus tentang administrasi keuangan dan perkoperasian.

c. Penguatan pengelolaan keuangan dengan fasilitasi penguatan administrasi dan pelaporan keuangan serta fasilitasi peningkatan simpanan anggota.

d. Peningkatan pengetahuan tentang manajemen kelembagaan bagi pengurus dalam melakukan pengelolaan simpan pinjam.

e. Penguatan manajemen dengan melakukan fasilitasi peningkatan kapasitas pengurus dan anggota kelompok dalam wadah kelompok ataupun manajemen.

f. Peningkatan pemahaman dan motivasi kewirausahaan.

\section{TINJAUAN PUSTAKA}

a. Kelompok dan organisasi sebagai institusi masyarakat

Dalam usaha meningkatkan taraf dan kualitas hidup masyarakat pedesaan perlu digali cara-cara pengelolaan usaha yang paling sesuai, salah satu potensi yang dapat dikembangakan adalah pembinaan kelompok-kelompok masyarakat sebagai media peningkatan taraf dan kualitas hidup mereka. Brown dan Moberg (Ruwiyanto,1988) mengungkapkan bahwa organisasi berada dalam dalam kontinum individu-masyarakat. Mereka berdua menyebutkan bahwa masyarakat itu merupakan gabungan dari komunitas. Komunitas merupakan gabungan dari organisasi. Organisasi merupakan gabungan dari 
kelompok, dan kelompok merupakan gabungan dari individu. Browm dan Moberg juga menyebutkan bahwa guna mempelajari individu dan kelompok, digunakan pendekatan yang mereka sebut pendekatan mikro, sedangkan guna mempelajari komunitas dan masyarakat perlu menggunakan pendekatan makro.

Kelompok masyarakat diharapkan bukanlah kelompok tanpa kemajuan, tetapi kelompok masyarakat harus berkembang menuju kepada perkembangan dan kemajuan. Untuk itu para anggota bisa diminta untuk mendefinisikan tahap-tahap perkembangan kelompok sebagai langkah yang akan ditempuhnya. Tahap-tahap tersebut akan menjadi acuan program pengembangan kelompok dan anggota untuk mencapainya secara bersamasama (Karsidi, 1998).

Menurut Raharjo (1989) mendasarkan pada kelompok kepentingan ekonomi, ada tiga tahap kemajuan kelompok. Tahap pertama dapat disebut sebagai kelompok swakarsa, kemudian kelompok swakarya dan terakhir adalah kelompok mandiri. Kelompok yang berada dalam suatu tahapan diharapkan akan terus berkembang menuju ke tahapan berikutnya sehingga menjadi kelompok yang mandiri.

b. Kelompok simpan pinjam sebagai embrio koperasi simpan pinjam

Keberadaan kelompok simpan pinjam di wilayah pedesaan harus dikembangkan dan terus dibina sehingga diharapkan bisa berkembang menjadi koperasi simpan pinjam. Koperasi Simpan Pinjam Adalah koperasi yang bergerak di bidang simpanan dan pinjaman. Sesuai dengan pengertian koperasi, didalam koperasi selalu terdapat unsurunsur sosial sekaligus unsur ekonomi. Walaupun kedua unsur tersebut berbeda, namun satu sama lainnya saling berkaitan menjadi satu kesatuan .(Rudianto,2006:1). Koperasi adalah organisasi ekonomi yang harus memepertahankan kelangsungan hidupnya, bahkan kalau bisa terus dikembangkan. Agar dapat berkembang maka kopersai harus dikelola dengan manajemen yang profesional.

c. Akuntansi dan aktivitas Koperasi

Tujuan didirikannya koperasi adalah untuk memberikan kesejahteraan dan manfaat bagi anggotanya dan masyarakat pada umumnya. Agar tujuan terebut dapat tercapai maka setiap koperasi harus mampu menghasilkan laba usaha yang harus dapat dilaporkan dalam Laporan Keuangan secara periodik dalam system akuntansi yang teratur dan terpercaya. Akuntansi adalah sistem informasi yang menghasilkan laporan kepada pihakpihak yang berkepentingan mengenai aktivitas ekonomi dan kondisi suatu badan usaha. (Rudianto, 2005:13). Dalam proses menghasilkan informasi yang dibutuhkan oleh berbagai pihak yang berkepentingan, akuntansi harus melewati beberapa tahapan proses. Proses tersebut dimulai dari mengumpulkan dokumen dasar transaksi, mengklasifikasikan jenis transaksi, menganalisa, meringkasnya dalam catatan dan sampai dengan melaporkannya dalam bentuk laporan keuangan yang dibutuhkan; proses tersebut dinamakan siklus akuntansi.

Macam Laporan Keuangan Koperasi:

Sesuai dengan standar akuntansi keuangan yang berlaku di Indonesia mulai tahun 2004 PSAK N0.27 tahun 2004, Laporan keuangan koperasi terdiri dari:

1) Perhitungan Hasil Usaha

Adalah suatu laporan yang menunjukkan kemampuan koperasi dalam menghasilkan profit dalam suatu periode akuntansi tau satu tahun. Laporan hasil Usaha harus 
merinci mengenai hasil usaha yang berasal dari anggota dan profit yang diperoleh dari aktivitas koperasi yang berasal dari bukan anggota.

2) Neraca

Dalam suatu daftar yang menunjukkkan posisi sumber daya yang dimiliki koperasi, serta informasi dari mana sumberdaya tersebut diperoleh

3) Laporan arus Kas

Adalah suatu laporan mengenai arus keluar masuknya kas di dalam suatu periode tertentu, yang mencakup saldo awal kas, sumber penerimaan kas, sumber pengeluaran kas dan saldo akhir kas pada suatu periode.

4) Laporan promosi Ekonomi Anggota

Adalah Laporan yang menunjukkkan manfaat ekonomi yang diterima angggota koperasi selama suatu periode tertentu. Laporan tersebut mencakup 4 unsur, yaitu sebagai berikut:

a) manfaat ekonomi dari pembelian barang atau pengadaan jasa bersama.

b) Manfaat ekonomi dari pemasaran dan pengolahan bersama

c) Manfaat ekonomi dari simpan pinjam lewat koperasi

d) Manfaat ekonomi dalam bentuk pembagian SHU

Anggota koperasi diharapkan mengetahui dan memahami tentang Akuntansi koperasi sehingga bisa bersinergi dengan para Fungsionaris koperasi yang lain dalam mengembangkan koperasi.

\section{d. Kewirausahaan}

Kewirausahaan adalah kemampuan menciptakan sesuatu yang baru secara kreatif dan inovatif untuk mewujudkan nilai tambah (Overton, 2002). Kreatif berarti menghasilkan sesuatu yang belum pernah ada sebelumnya. Inovatif berarti memperbaiki/memodifikasi/mengembangkan sesuatu yang sudah ada. Nilai tambah berarti memiliki nilai lebih dari sebelumnya. Ada yang berpendapat bahwa istilah kewirausahaan itu merupakan singkatan dari: Kreatif, Enerjik, Wawasan luas, Inovatif, Rencana bisnis, Agresif, Ulet, Supel, Antusias, Hemat, Asa, Ambisi, Negosiatif. (Anonim 1, 2005). Sebenarnya, masih banyak lagi sifat-sifat yang harus dimiliki seorang wirausaha misalnya berani mengambil risiko dengan penuh perhitungan, mampu memanfaatkan peluang, komunikatif, mampu memasarkan, mampu bernegosiasi.

Seorang wirausahawan yang sukses harus memiliki tiga kompetensi pokok yaitu pengetahuan, keterampilan, dan sikap kewirausahaan. Ketiga kompetensi tersebut saling berkaitan. Kompetensi merupakan penguasaan pengetahuan, keterampilan, dan sikap. Pengetahuan adalah kumpulan informasi yang disimpan di otak dan dapat dipanggil jika dibutuhkan.Keterampilan adalah kemampuan menerapkan pengetahuan. Sikap adalah sekumpulan kualitas karakter yang membentuk kepribadian seseorang (Anonim 4, 2005).

\section{METODE PELAKSANAAN}

Metode pelaksanaan yang digunakan dalam realisasi program Ipteks bagi Masyarakat ini adalah penyuluhan, pelatihan dan pendampingan, yang meliputi:

a) Penyuluhan 
Penyuluhan dilakukan dengan metode ceramah dan diskusi tentang pentingnya Pengembangan pengetahuan dan ketrampilan dalam berwirausaha, tentang pentingnya penertiban Administrasi pembukuan dan Penyusunan Job Description Pengurus. Dalam penyuluhan ini, setelah ceramah dilakukan maka dibuka sesi tanya jawab bagi yang kurang jelas. Penyuluhan ini dimaksudkan untuk memberi pemahaman bagi semua anggota kelompok tentang pentingnya Pengembangan pengetahuan dan ketrampilan Kewirausahaan, Tertib Administrasi Pembukuan dan Pembagian Kerja dalam Kelompok PEW untuk penguatan kapasitas kelembagaan/ organisasi kelompok.

b). Pelatihan

Pelatihan diberikan kepada pengurus kelompok usaha simpan pinjam. Metode Pelatihan meliputi beberapa bentuk kegiatan, yaitu berupa ceramah, curah pendapat,permaian (games) serta praktek laboratorium belajar komputer. Metode pelatihan ini diberikan untuk memberi solusi atas permasalahan yang telah disepakati bersama mitra.

c). Pendampingan

Pendampingan adalah kegiatan yang bertujuan untuk memberikan penguatan terhadap proses implementasi konsep penyuluhan dan pelatihan yang telah dilakukan,mendampingi kelompok masyarakat dalam rangka supervisi kegiatan pembenahan administrasi pembukuan keuangan, ketrampilan menggunakan komputer, manajemen kelembagaan kelompok dan pendampingan dalam penyusunan $\mathrm{AD} / \mathrm{ART}$ kelompok. Pendampingan dilakukan dengan melakukan petemuan secara berkala dengan kelompok masyarakat, dalam fase ini akan menjadi ajang konsultasi dan tukar pengalaman (sharing lesson-learned). Pendampingan adalah kegiatan yang bertujuan untuk memberikan penguatan terhadap proses implementasi konsep penyuluhan dan pelatihan yang telah dilakukan.

\section{HASIL DAN PEMBAHASAN}

Hasil yang telah dilakukan dan dicapai dalam pengabdian ini meliputi pengatasan beberapa masalah yang dihadapi Kelompok PEW mitra, yaitu: Sistem administrasi dan pengelolaan keuangan yang masih sangat sederhana diatasi dengan pelatihan dan pendampingan administrasi pembukuan kelompok PEW, rendahnya kegiatan usaha produktif (kewirausahaan) anggota kelompok dalam memanfaatkan pinjaman dana untuk peningkatan kesejahteraan dengan pelatihan kewirausahaan, masih rendahnya pemahaman tentang aturan kelembagaan dan pembagian kerja kelompok diatasi dengan penyuluhan kelembagaan dan pendampingan penyusunan Job Description dan peraturan kelompok.

Tahapan Pelaksanaan kegiatan pengabdian masyarakat ini meliputi tujuh (7) kegiatan, yang terdiri dari :

1. Sosialisasi kegiatan kepada kedua mitra

Sosialisi ini bertujuan memberikan gambaran dan pemahaman tentang kegiatan pelatihan dan pendampingan yang akan diberikan kepada mitra kelompok simpan pinjam. Kegiatan ini disambut baik oleh kedua mitra kelompok, terbukti dengan antusiasme anggota kelompok yang hadir untuk melakukan tanya jawab dan diskusi dengan tim pengabdi. 
2. Pelatihan administrasi dan Pembukuan Kelompok

Pelatihan administrasi dan pembukuan Kelompok PEW ini bertujuan agar para peserta pelatihan menguasai konsep dan mekanisme pengelolaan keuangan secara efisien dan efektif dengan pola pengelolaan administrasi keuangan serta administrasi umum kelompok simpan pinjam . Administrasi keuangan atau pembukuan keuangan adalah catatan transaksi keuangan yang dibuat secara kronologis dan sistematis. Administrasi keuangan juga dapat diartikan sebagai pencatatan yang berkaitan dengan kekayaan kelompok. Sangat penting untuk mengetahui keadaan kekayaan kelompok dengan jelas/transparan dan sebagai alat untuk pengawasan dalam pengelolaan permodalan kelompok. Sedemikian pentingnya administrasi keuangan ini sehingga dapat dikatakan bahwa nilai administrasi keuangan ini setara dengan nilai uangnya atau bahkan lebih daripada itu.

Sedangkan Administrasi organisasi umum berkaitan dengan segala aktivitas organisasi secara umum yaitu pencatatan yang dilakukan atas segala aktivitas atau kegiatan kelompok yang dilakukan secara periodik.

Setelah kegiatan pelatihan Peserta pelatihan diharapkan dapat membenahi administrasi umum maupun administrasi keuangan di masing -masing kelompoknya, sehingga pencatatan seluruh aktivitas organisasi kelompok secara umum maupun yang berkaitan dengan keuangan dapat diadministrasikan secara tertib. Sehingga pada akhir periode pengurus dapat menyusun laporan kinerja secara lengkap. Peserta pelatihan juga dapat memahami dan mengaplikasikan standar operasional pembagian SHU. Sehingga dengan pelatihan ini diharapakan dapat mengatasi permasalahan Sistem administrasi dan pengelolaan keuangan masih sangat sederhana di kedua mitra kelompok PEW. Outcome pelatihan administrasi dan akuntansi adalah peningkatan pengetahuan dan ketrampilan peserta dalam pengelolaan administrasi umum dan keuangan kelompok .

Materi pelatihan administrasi dan akuntansi kelompok PEW yang disampaikan kepada peserta , terdiri dari :

1) Manajemen Kelembagaan Kelompok

2) Administrasi organisasi umum

3) Penyuluhan Penyusunan Job Description dan peraturan Kelompok

4) Administrasi Keuangan Kelompok PEW

5) Standar perhitungan pembagian SHU Kelompok simpan pinjam

6) Laporan keuangan Kelompok

Setelah diadakan evaluasi dengan cara Pre Test dan Post Test dapat dketahui bahwa sebelum pelatihan semua peserta tidak dapat membukukan investasi modal atau modal usaha, tidak dapat menghitung dan mengalokasikan SHU dari usahanya sendiri maupun Kelompok PEW, tidak dapat membukukan SHU sesuai dengan alokasi yang telah ditentukan, dan tidak dapat menyusun laporan keuangan sesuai format, tetapi setelah mengikuti pelatihan $75 \%$ peserta menyatakan dapat membukukan investasi modal-modal koperasi, dapat menghitung dan mengalokasikan SHU Kelompok PEW, dapat membukukan SHU sesuai dengan alokasi yang telah ditentukan, dan dapat menyusun laporan keuangan sesuai format.

Dengan demikian secara keseluruhan setelah mengikuti pelatihan terdapat peningkatan pengetahuan tentang administrasi dan akuntansi ,hal ini terlihat rata-rata 
persentase peserta yang menyatakan memahami materi yang diberikan sebesar $85,94 \%$. Meskipun rata-rata masih terdapat $14,06 \%$ peserta yang belum dapat memahami materi yang diberikan. Untuk menambah pemahaman dan ketrampilan peserta pelatihan akan dilakukan pendampingan kepada kedua kelompok mitra, sebagai kelanjutan dari pelatihan.

3. Pelatihan Kewirausahaan

Pelatihan Kewirausahaan dirancang untuk mendorong minat peserta sekaligus mempersiapkan peserta untuk menjadi wirausaha. Dengan berbagai latihan, diharapkan peserta dapat mulai membangun usaha, dari usaha-usaha yang sederhana hingga akhirnya mereka lebih berani memulai usaha yang lebih besar dan lebih komplek . Keterampilan-keterampilan yang berifat soft skill, yang berhubungan dengan karakter seorang entrepreneur perlu dibangun disini. Karakter-karakter itu secara umum adalah berani mengambil inisiatif dan risiko, terbuka dan mampu mengungkapkan isi hati dan pikiran, persuasif, pemimpin yang bertanggungjawab, pekerja keras, menjunjung tinggi nilai-nilai kejujuran, dan seorang yang mampu melihat jauh ke depan.

Pelatihan ini dirancang dengan 4 pendekatan, yaitu:

\section{1). Soft skill dan Hard skill}

Kewirausahaan adalah gabungan dari soft skill \& hard skill. Dengan pemberian keterampilan-keterampilan melihat/membaca peluang dan risiko, berpikir praktis dan kratif dan membangun kapabilitas diri (kepemimpinan dan pengorganisasian) akan sama pentingnya dengan keterampilan-keterampilan manajerial (seperti pemasaran dan keuangan).

2). indoor games

Pelatihan ini juga akan diisi oleh beberapa indoor games untuk mengasah keterampilan berwirausaha. Untuk itu seluruh peserta didorong agar berpartisipasi dan mengevaluasi diri sehingga menimbulkan kesadarankesadaran baru untuk menjadi entrepreneur.

3). Inspiring Sessions

Pelatihan ini akan diisi oleh beberap Inspiring Sessions. Pelatih akan memutar beberapa video dokumentasi tentang beberapa kisah sukses dalam memulai usaha. Disamping itu kelas juga akan diisi ceramah dari praktisi/pengusaha.

4. Latihan lapangan dan pendampingan

Tanpa latihan lapangan sulit diperoleh pengalaman riil. Maka pelatihan ini dirancang dengan beberapa tugas lapangan yang riil untuk mengasah DNA kewirusahaan dan intiusi membaca peluang dan risiko.setelah pelatian ini diharapkan peserta dapat membuat rancangan bisnis yang kemudian dipraktekan, yang dilanjutkan dengan kegiatan pendampingan dari para nara sumber .

Outcome dari kegiatan Pelatihan kewirausahaan adalah terjadi peningkatan minat dan semangat berwirausaha, serta peningkatan kegiatan kewirausahaan para peserta pelatihan. Para peserta pelatihan diharapkan mampu memahami karakter yang harus dimiliki wirausahawan. Adapun materi yang diberikan meliputi:

1) Berpikir perubahan,kreatif dan berorientasi pada tindakan

2) Kepemimpinan

3) Etika bisnis 
4) Mencari gagasan usaha dan pemasaran usaha

5) Memulai sebuah usaha baru \& Perencanaan Bisnis.

\section{Pelatihan dan praktek komputer}

Pelatihan dan praktek komputer ini bertujuan untuk meningkatkan pengetahuan dan ketrampilan menggunakan komputer untuk menunjang kegiatan administrasi kelompok simpan pinjam. Materi pelatihan meliputi program komputer office : MS. Word dan Ms. Excel. Peserta pelatihan sangat antusias mengikuti pelatihan dan praktek komputer, hal ini dapat dilihat dari antusiasme dari seluruh peserta dalam mengajukan pertanyaan pada sesi praktek komputer. Sebagian besar peserta juga belum terampil mengoperasikan komputer.

\section{Penyerahan Bantuan Komputer/ Notebook Kepada Mitra}

Penyerahan bantuan komputer kepada masing-masing kelompok tersebut dimaksudkan untuk menunjang kegiatan administrasi kelompok PEW. Bantuan komputer diberikan kepada masing masing Kelompok Mitra.

\section{Pendampingan Kepada Mitra Kegiatan}

Sebagai tindak lanjut dari progam pelatihan kepada kedua mitra dalam pelaksanaan kegiatan Ipteks bagi masyarakat ini diadakan kegiatan pendampingan bagi kedua kelompok PEW yang menjadi mitra kegiatan. Kegiatan pendampingan ini dilakukan satu minggu setelah pelatihan dengan kunjungan Tim Pengabdi ke lokasi mitra yaitu Kelompok PEW Hidayah dan Kelompok PEW Chasanah di Kelurahan Pringgokusuman, Kecamatan Gedongtengen, Kota Yogyakarta. Daerah Istimewa Yogyakarta. Penyusunan jadwal pendampingan ditentukan berdasarkan kesepakatan antara Tim Pengabdi dengan kelompok mitra.

Pendampingan dilakukan terkait dengan materi pelatihan yang meliputi kegiatankegiatan : Penataan administrasi dan pembukuan kelompok, kewirausahaan, pendalaman pemahaman tentang tata cara penyusunan peraturan organisasi/kelompok, serta praktek penggunaan computer. Pendampingan dilakukan selama 2 bulan secara intensif.

Untuk pendampingan praktek computer, oleh karena kedua kelompok simpan pinjam belum memiliki computer, maka bantuan netbook yang diberikan oleh tim pengabdi kepada kedua kelompok mitra menjadi sangat berarti dan bermanfaat. Selain itu bantuan network yang diberikan juga sangat membantu pengurus Kelompok PEW untuk kelancaran operasional administrasi kelompok. Tim Pengabdi juga mendapingi kedua kelompok simpan pinjam dalam proses penyusunan laporan keuangan dan laporan kegiatan Kelompok PEW.

Kegiatan pendampingan, sangat diperlukan agar mitra pelaksanaan kegiatan ini lebih memahami materi yang disampaikan dan dapat mengaplikasikannya dalam penataan dan penyempurnaan kegiatan kelpompok. Hal-hal yang dicapai dari kegiatan pendampingan ini adalah:

1) Tumbuhnya semangat kewirausahaan dengan terbentuknya usaha produktif anggota.

2) Peningkatan ketrampilan pengurus dalam mengoperasikan computer dengan bantuan hibah computer (netbook). Untuk kelompok mitra, peningkatan ketrampilan tersebut diharapkan dapat memperlancar ketrampilan pengurus dan dapat menunjang kegiatan operasinal simpan pinjam.

3) Terciptanya administrasi pembukuan simpan pinjam yang tertib., Masing-masing kelompok sudah dapat mempraktekkan siklus akutansi dalam perhitungan pnjaman 
secara bergulir pada kegiatan Kelompok PEW. Dalam laporan pertanggunjawaban pengurus juga telah dapat mencantumkan Rencana Kerja dan Rencana Anggaran.

\section{KESIMPULAN}

Berdasarkan hasil pelaksanaan kegiatan IbM yang telah dilakukan di Kelompok PEW Hidayah dan Kelompok PEW Chasanah di Kelurahan Pringgokusuman, Kecamatan Gedongtengen, Kota Yogyakarta. Daerah Istimewa Yogyakarta seperti telah diuraikan pada bab terdahulu, maka dari kegiatan tersebut dapat disimpulkan hal-hal sebagai berikut:

1. Target kegiatan Penyuluhan tentang tata cara penyusunan AD/ART, dapat tercapai. Peserta pelatihan dapat mengetahui dan memahami tentang pedoman dan tatacara penyusunan anggaran Dasar dan Anggaran Rumah tangga

2. Target kegiatan Pelatihan Administrasi dan pembukuan kelompok dapat tercapai. Hal ini ditunjukkan dengan adanya peningkatan pengetahuan dan ketrampilan peserta dalam pengelolaan administrasi kelompok simpan pinjam dan pembukuan akuntansi simpan pinjam. Peserta juga telah memahami konsep dan mekanisme pengelolaan keuangan simpan pinjam. Peserta juga dapat menyusun laporan keuangan, baik laporan Neraca, laporan Hasil Usaha, laporan perubahan Modal dan laporan Arus Kas.

3. Kegiatan pelatihan manajemen kelembagaan dapat meningkatkan pengetahuan pengurus tentang manajemen kelembagaan.

4. Kegiatan Pelatihan \& Praktek komputer meningkatkan kemampuan dan ketrampilan peserta pelatihan dalam mengopersionalkan komputer dan dan dapat memanfaatkan software Ms office excel untuk pendukung pengelolaan Kelompok PEW

5. Pelatihan kewirausahaan memberikan dan meningkatkan pengetahuan peserta pelatihan tentang kewirausahaan, sehingga menumbuhkan kreatifitas dan keinginan berwirausaha bagi peserta pelatihan.

\section{DAFTAR PUSTAKA}

Chaniago, Arifinal, 1982. Perkoperasian Indonesia, Bandung: Angkasa.

Garvin, Charles,1986. Contemporary Group Work. Prentice Hall Inc, New Jersey, Englewood Cliff.

Gita Pertiwi. 2010. Training Modul Konsep Dasar Kelompok, Sumber dan Penggunaan Dana Kelompok, Pembukuan Keuangan Kelompok, Colomadu. Griyan lama.

Gunardi, Seldadyo H. dkk, 1994. Kredit untuk Rakyat, dari Mekanisme Arisan Hingga $B P R$, Bandung: Akatiga.

Soekanto, Soerjono, 2005. Sosiologi Suatu Pengantar. Jakarta: CV Rajawali. 
Sumodiningrat, Gunawan, 1997. Pelayanan Kredit Untuk Masyarakat Lapisan Bawah", Bappenas, dalam Diskusi Ahli: Pemberdayaan dan Replikasi Aspek Finansial Usaha Kecil Di Indonesia", Editor Erna Ermawati Chotim dan Juni Thamrin, 1997, Bandung: Yayasan Akatiga, PEP LIPI, Yayasan Mitra Usaha, The Asia Foundation.

Verhagen, Koenraad, 1996. Self-Help Promotion, A Challenge to NGO Community, Cebemo/Royal Tropical Institute The Netherlands.

Zainuddin, M, 1997. Memberdayakan Ekonomi Rakyat Refleksi dan Replikasi ModelModel Finansial Untuk Usaha Kecil, Tinjauan Dari Sisi Penawaran dalam Diskusi Ahli: Pemberdayaan dan Replikasi Aspek Finansial Usaha Kecil Di Indonesia, Editor Erna Ermawati Chotim dan Juni Thamrin, 1997, Bandung: Yayasan Akatiga, PEP LIPI, Yayasan Mitra Usaha, The Asia Foundation. 